\title{
Artikel Review
}

\section{Terapi Kanker dengan Radiasi: Konsep Dasar Radioterapi dan Perkembangannya di Indonesia}

\author{
Nur Fitriatuzzakiyyah, Rano K. Sinuraya, Irma M. Puspitasari \\ Departemen Farmakologi dan Farmasi Klinik, Fakultas Farmasi, \\ Universitas Padjadjaran, Sumedang, Indonesia
}

\begin{abstract}
Abstrak
Kanker merupakan salah satu penyakit yang menyebabkan kematian yang tinggi di dunia. Berdasarkan data WHO, pada tahun 2015 terdapat 8,8 juta kematian yang diakibatkan oleh penyakit kanker. Berdasarkan data riskesdas tahun 2013, prevalensi kanker di Indonesia mencapai 1,4\% atau sekitar 347.792 orang. Berbagai metode telah dikembangkan untuk mengobati kanker, salah satunya dengan menggunakan terapi radiasi atau radioterapi. Berdasarkan International Agency for Research on Cancer (IARC), dari 10,9 juta orang yang didiagnosis menderita kanker di seluruh dunia setiap tahun, sekitar $50 \%$ membutuhkan radioterapi. Penggunaan radiasi untuk terapi kanker belum banyak digunakan dan masih terbatas di Indonesia. Tujuan penulisan review ini adalah untuk memaparkan konsep dasar terapi kanker dengan radiasi dan perkembangan radioterapi di Indonesia melalui penelusuran pustaka. Metode penelusuran pustaka dalam artikel review ini adalah penelusuran pustaka pada mesin pencari Google, Google Scholar dan PubMed basis data dengan kata kunci "basic radiotherapy" "radiation therapy in Indonesia" "novel radiotherapy in Indonesia" serta peraturan perundang-undangan Republik Indonesia yang berkaitan dengan radioterapi. Hasil penelusuran pustaka menunjukkan bahwa teknologi radiasi telah ada di Indonesia sejak tahun 1927. Sampai tahun 2013, terdapat 29 pusat pelayanan radioterapi di Indonesia. Radioterapi telah menjadi salah satu terapi yang penting dalam pengobatan kanker di Indonesia. Pemerintah Indonesia mendukung kemajuan teknologi ini dengan menerbitkan peraturan tentang standar pelayanan radioterapi di rumah sakit. Semakin banyak dan berkembangnya fasilitas radioterapi diharapkan dapat mengurangi prevalensi penyakit kanker di Indonesia.
\end{abstract}

Kata kunci: Kanker, radioterapi, regulasi, terapi radiasi

\section{Cancer Therapy with Radiation: The Basic Concept of Radiotherapy and Its Development in Indonesia}

\begin{abstract}
Cancer is one of the leading causes of death worldwide. According to WHO, 8,8 million deaths in 2015 was caused by cancer. In Indonesia, based on basic health research data in 2013, the prevalence of cancer was $1.4 \%$ or 347.792 people in Indonesia suffer from cancer. Various methods have been developed to treat cancer, one of them is by using radiation therapy or radiotherapy. According to International Agency for Research on Cancer (IARC), from 10.9 million people diagnosed with cancer, about $50 \%$ require radiotherapy. The use of radiation for cancer therapy has not been widely used and is still limited in Indonesia. This review article was aimed to describe the basic concept of cancer therapy with radiation and its development in Indonesia. Literature review was conducted from Google search engine, Google Scholar and PubMed database with keyword "basic radiotherapy" "radiation therapy in Indonesia" "novel radiotherapy in Indonesia" and radiotherapy regulations in Indonesia. The results revealed that radiation technology has been availabe in Indonesia since 1927. Until 2013, 29 radiotherapy centers were available in Indonesia. Radiotherapy has become one of important modalities for cancer treatment in Indonesia. Indonesian government supports the development of this technology, by issuing regulations on radiotherapy service standards in hospitals. More technology development and radiotherapy facilities are expected to reduce the prevalence of cancer in Indonesia.
\end{abstract}

Keywords: Cancer, radiation therapy, radiotherapy, regulation

Korespondensi: Irma M. Puspitasari, PhD., MT., Apt. Departemen Farmakologi dan Farmasi Klinik, Fakultas Farmasi, Universitas Padjadjaran, Sumedang, Jawa Barat 45363, Indonesia, email: irma.melyani@unpad.ac.id Naskah diterima: 5 Oktober 2017, Diterima untuk diterbitkan: 2 November 2017, Diterbitkan: 1 Desember 2017 


\section{Pendahuluan}

Prevalensi kanker di Indonesia berdasarkan data riskesdas tahun 2013 mencapai 1,4\% atau sekitar 347.792 orang, dengan prevalensi terbesar yaitu kanker serviks sebesar 0,8\% dan kanker payudara sebesar $0,5 \% .{ }^{1}$ Terdapat beberapa metode yang dapat digunakan untuk terapi kanker, yaitu pembedahan, kemoterapi atau disebut juga kemo, imunoterapi, targeted therapy, terapi hormon atau terapi endokrin, transplantasi sel induk dan terapi radiasi. ${ }^{2}$ Radioterapi atau terapi radiasi adalah terapi non-bedah terpenting untuk pengobatan kuratif kanker. Dari 10,9 juta orang yang didiagnosis menderita kanker di seluruh dunia setiap tahun, sekitar 50\% memerlukan radioterapi dan $60 \%$ di antaranya diobati dengan kuratif. Biaya untuk radioterapi juga sangat hemat, terhitung hanya $5 \%$ dari total biaya perawatan kanker. ${ }^{3}$

Pengobatan kanker di Indonesia saat ini banyak menggunakan kemoterapi dan proses pembedahan. Penggunaan terapi kanker dengan radiasi belum banyak digunakan dan masih terbatas. Oleh karena itu, dalam artikel review ini akan dibahas mengenai konsep dasar radioterapi serta perkembangannya di Indonesia.

\section{Metode}

Pada penulisan artikel review ini, metode yang digunakan adalah penelusuran pustaka berupa teori serta data penelitian-penelitian yang berkaitan dengan konsep dasar radiasi beserta penggunaannya dalam terapi kanker/ radioterapi pada mesin pencari Google, Google Scholar dan PubMed basis data dengan kata kunci "basic radiotherapy", "radiation therapy in Indonesia", "novel radiotherapy in Indonesia" dan peraturan perundang-undangan Republik Indonesia terkait radiasi serta penggunaannya sebagai radioterapi. Tidak ada pembatasan index maupun impact factor pada artikel penelitian yang diperoleh dari penelusuran pustaka.

\section{Hasil}

Referensi yang diperoleh dari penelusuran pustaka adalah berupa artikel penelitian, laporan Kementerian Kesehatan Republik Indonesia dan peraturan perundang-undangan Republik Indonesia. Artikel penelitian yang diperoleh menggunakan bahasa Inggris dan bahasa Indonesia. Jumlah referensi yang dipilih adalah sebanyak 40 referensi, 32 $(80 \%)$ di antaranya adalah artikel jurnal tanpa pembatasan index maupun impact factor dan $8(20 \%)$ merupakan referensi penunjang berupa laporan WHO, peraturan perundangundangan dalam bentuk undang-undang Republik Indonesia, peraturan pemerintah serta peraturan menteri kesehatan.

\section{Pembahasan}

Konsep dasar radioterapi

Radiasi merupakan perpindahan energi dari sumber radiasi terhadap medium lain, dan transmisi ini dapat berupa partikel (radiasi partikel) maupun berupa gelombang atau cahaya (radiasi elektromagnetik). ${ }^{4}$ Beberapa jenis radiasi yang dihasilkan dari atom, seperti radiasi sinar tampak, sinar- $\mathrm{X}$ dan sinar- $\gamma$, dikelompokkan dalam gelombang elektomagnetik atau dikenal dengan istilah spektrum elektromagnetik. Pada spektrum ini, gelombang radio dengan panjang gelombang $\geq 10-7 \mathrm{~nm}$ dan memiliki energi $<12 \mathrm{eV}$ termasuk ke dalam radiasi non-ionik, seperti sinar inframerah, sinar tampak, sinar ultraviolet, sedangkan gelombang radio dengan energi $>12 \mathrm{eV}$, seperti sinar-X dan sinar- $\gamma$ disebut radiasi pengion. ${ }^{4,5}$ Dalam radioterapi, digunakan radiasi pengion karena dapat membentuk ion (partikel bermuatan listrik) dan menyimpan energi ke sel-sel jaringan yang melewatinya. Energi yang 
tersimpan ini bisa membunuh sel kanker atau menyebabkan perubahan genetik yang mengakibatkan kematian sel kanker. ${ }^{5}$ Radiasi pengion adalah radiasi dengan energi tinggi yang mampu melepaskan elektron dari orbit suatu atom, yang menyebabkan terbentuknya muatan atau terionisasi. Radiasi pengion terdiri dari radiasi elektromagnetik dan radiasi partikel. $^{5}$

\section{Radiasi elektromagnetik}

Radiasi elektromagnetik merupakan radiasi ketika energi dibawa oleh osilasi medan listrik dan medan magnet yang merambat pada kecepatan cahaya, contohnya radiasi sinar- $\mathrm{X}$ dan sinar- $\gamma$ dan merupakan jenis yang paling umum digunakan dalam radioterapi. ${ }^{5}$ Sinar-X diproduksi saat elektron berkecepatan tinggi bertabrakan dengan material yang memiliki nomor atom tinggi seperti tungstenmolibdenum pada anoda tabung sinar-X, sedangkan sinar gamma secara fisik identik dengan sinar-X, namun dipancarkan dari inti atom (intranuclearly) atau berasal dari radioactive decay seperti Cobalt-60, Radium dan Cesium. Inti atom yang tidak stabil melepaskan energi berlebihnya dalam bentuk elektron intranuklear (partikel beta) atau inti helium (sebuah partikel alfa). Jika masih memiliki kelebihan energi setelah itu, sinar gamma dipancarkan untuk mencapai steady state. $^{5,6}$

\section{Radiasi partikel}

Radiasi partikel adalah radiasi yang terdiri dari partikel atom atau subatomik (elektron dan proton) yang membawa energi dalam bentuk energi kinetik atau massa yang bergerak. ${ }^{6}$ Radiasi partikel terdiri dari elektron, proton dan neutron beams. Electron beams merupakan salah satu metode konvensional yang telah lebih dahulu digunakan. Biasanya digunakan dalam terapi radiasi sehari-hari dan sangat berguna pada terapi tumor yang dekat dengan permukaan tubuh karena tidak menembus ke dalam jaringan. ${ }^{6,7}$ Proton beams merupakan radiasi partikel yang lebih baru digunakan untuk mengobati kanker. Radiasi ini memiliki distribusi dosis yang lebih baik karena profil penyerapannya yang unik dalam jaringan yang dikenal sebagai puncak Bragg (Bragg peak) sehingga memungkinkan terjadi pengendapan energi destruktif dengan maksimal di lokasi tumor dan meminimalkan kerusakan pada jaringan sehat di sepanjang jalur kerjanya. Dalam aplikasi klinis, radiasi ini sangat berguna untuk terapi tumor pediatrik dan dewasa yang berada di dekat bagian vital seperti tumor tulang belakang dan tumor tengkorak, karena paparan radiasi terhadap jaringan normal sangat penting untuk diminimalkan. ${ }^{8,9}$ Neutron beams mampu mendeposit energi secara maksimal pada target jaringan di ujung lintas terapinya. Secara keseluruhan radiasi partikel memilliki Linear Energy Transfer (LET) yang lebih tinggi daripada radiasi foton, namun karena biaya produksinya yang mahal penggunaan jenis radiasi ini masih terbatas..$^{9,10}$

Jenis radioterapi

Radioterapi dapat digunakan sebagai terapi kuratif, paliatif maupun profilaksis (preventif). Terapi kuratif biasanya berbentuk terapi tunggal untuk penyembuhan suatu kanker, contohnya digunakan dalam kasus limfoma Hodgkin tahap awal, kanker nasofaring, beberapa kanker kulit, dan kanker glotis awal. Terapi paliatif bertujuan untuk meningkatkan kualitas hidup dengan cara menghilangkan gejala-gejala kanker dengan menerapkan dosis radiasi paliatif. Penerapannya antara lain pada kasus maternal otak dan tulang serta sindroma venacava superior. Terapi profilaksis (preventif) merupakan terapi yang bertujuan untuk mencegah kemungkinan metastasis atau kejadian berulang melalui penerapan radioterapi, contohnya adalah whole-barin radiotherapy untuk leukemia limfoblastik akut dan kanker paru-paru sel kecil..$^{10,11}$ 
Berdasarkan waktu penggunaannya, radioterapi terdiri dari radioterapi adjuvan yang diberikan setelah dilakukannya metode pegobatan tertentu, radioterapineoadjuvan, dan radiokemoterapi. Radioterapineoadjuvan dilakukan sebelum dilakukannya tindakan dengan metode lain, misalnya radioterapi preoperasi, sedangkan radiokemoterapi yaitu pemberian radioterapi yang dilakukan bersamaan dengan kemoterapi. ${ }^{11}$

Penghantaran radiasi terhadap lokasi kanker dapat dilakukan dengan dua metode, yaitu radioterapi eksternal dan brachytherapy (endocurientherapy atau disebut sealed-source radiotherapy). Radioterapi eksternal adalah radioterapi yang dipaparkan ke tubuh secara eksternal menggunakan mesin perawatan, sedangkan pada brachytherapy, sumber radiasi temporer atau permanen ditempatkan ke dalam rongga tubuh, metode ini digunakan dalam perawatan rutin kanker ginekologi dan prostat serta pada situasi yang membutuhkan perawatan berulang. ${ }^{12,13}$

Mekanisme radiasi membunuh sel

Target utama dari terapi radiasi adalah kerusakan molekul DNA pada jaringan target. Secara umum ada 2 jenis mekanisme kerusakan DNA akibat radiasi pengion, yaitu ionisasi langsung dan tidak langsung. Kerusakan karena ionisasi langsung biasanya disebabkan oleh radiasi partikel yang terjadi karena energi kinetik partikel dapat langsung merusak struktur atom jaringan biologi yang dilewatinya, sedangkan ionisasi tidak langsung umumnya disebabkan oleh radiasi elektromagnetik dengan cara membentuk elektron sekunder/ radikal bebas yang akan berinteraksi dengan DNA menyebabkan kerusakan. ${ }^{14,15}$ Kerusakan ini dapat berupa single strand breaks (SSB) dan double strand breaks (DSB). Kerusakan pada salah satu untai DNA (SSB) masih dapat diperbaiki oleh sel, sedangkan kerusakan pada untai ganda seringkali menyebabkan kematian sel. ${ }^{15,16}$
Terapi radiasi dapat mencapai efek terapeutiknya dengan menginduksi kematian sel melalui beberapa cara, yaitu:

\section{Apoptosis}

Apoptosis adalah suatu bentuk kematian sel terprogram yang ditandai dengan kondensasi/ fragmentasi kromatin, penyusutan sel, dan pengelupasan selaput membran sel. Dalam responnya terhadap radiasi, apoptosis terutama diamati pada sel sistem hematopoietic. ${ }^{17}$

\section{Autofagi}

Autofagi merupakan proses sel mencerna bagian dari sitoplasmanya sendiri untuk menghasilkan makromolekul dan energi. Hal ini ditandai dengan penyerapan protein dan/ atau organel dalam vesikel autofagi besar yang disebut autophagosomes, lalu peleburan dari vesikula dengan lisosom menyebabkan pembentukan autophagolysosomes dan degradasi konten di dalamnya menyediakan bahan untuk sintesis dan regenerasi de novo. Terdapat hubungan antara autofagi dengan apoptosis karena autofagi ditemukan pada sel saat gagal mengalami apoptosis dan autofagi termasuk kematian sel terprogram tipe II (apoptosis adalah tipe I). ${ }^{18,19}$

\section{Nekrosis}

Nekrosis adalah kematian sel yang tidak terkontrol, terjadi karena kondisi ligkungan yang ekstrim seperti perubahan $\mathrm{pH}$ ekstrim, kehilangan energi atau ketidakseimbangan ion, dapat terjadi karena infeksi, inflamasi, ataupun iskemia. Nekrosis ditandai dengan deformasi membran, penggembungan selular, kerusakan organel, dan pelepasan enzim lisosomal yang menyerang sel. Nekrosis juga sering diamati pada sel tumor dan dapat terjadi karena kerusakan DNA akibat radiasi meskipun belum jelas bagaimana mekanisme terjadinya nekrosis pasca radiasi. ${ }^{20,21}$

\section{Senescence}

Senescence merupakan keadaan sel secara 
permanen kehilangan kemampuannya untuk membelah, akan tetapi sel masih memiliki kemampuan metabolisme dan tidak menunjukkan perubahan fungsional. ${ }^{22}$

\section{Kematian mitosis}

Proses ini terjadi ketika sel mengalami proses mitosis yang tidak tepat akibat kerusakan DNA yang tidak diperbaiki, hal ini sering terjadi setelah proses irradiasi. Dalam hal ini kematian sel didefinisikan sebagai kehilangan kemampuan replikasi dan ketidakmampuan sel untuk memisahkan materi genetik dengan benar. ${ }^{23}$

Penggolongan kejadian tidak diinginkan pada terapi radiasi berdasarkan National Cancer Institute (NCI)

Tujuan terapi radiasi adalah memaksimalkan dosis radiasi ke sel kanker abnormal dan meminimalkan paparan terhadap sel normal yang berdekatan dengan sel kanker atau yang berada pada jalur radiasi, meskipun pada kenyataannya radiasi mampu merusak sel kanker maupun sel normal. ${ }^{24,25}$ Untuk mendeskripsikan kejadian-kejadian yang tidak diinginkan dari suatu terapi, NCI telah merilis terminologi deskriptif yang dapat digunakan untuk pelaporan kejadian yang tidak diinginkan (adverse event) yang disebut dengan Common Terminology Criteria for Adverse Events (CTCAE). Skala penilaian (severity) disediakan untuk setiap istilah kejadian yang tidak diinginkan, terdiri atas: ${ }^{26}$ Tingkat 1: Ringan, gejala asimtomatik atau ringan, hanya terjadi pada pengamatan klinis atau diagnostik, tidak diindikasikan untuk intervensi; Tingkat 2: Sedang, diindikasikan intervensi lokal atau non-invasif; Tingkat 3: Parah atau signifikan secara medis namun tidak mengancam jiwa, diindikasikan rawat inap atau perpanjangan rawat inap; Tingkat 4: Konsekuensi yang mengancam jiwa, diindikasikan untuk melakukan intervensi mendesak; Tingkat 5: Berupa kejadian tidak diinginkan yang terkait dengan kematian.

Beberapa efek samping terapi radiasi yang telah dilaporkan antara lain:

1. Toksisitas kulit akut

Kejadian toksisitas pada kulit dilaporkan pada pasien yang menjalani terapi Stereotactic Body Radiation Therapy (SBRT), dalam penelitian Hoppe et al. tahun 2008, subjek yang mengalami toksisitas kulit tingkat 1,2 dan 3 berturut-turut sebesar 38\%, $8 \%$ dan $4 \% .^{27}$

\section{Komplikasi Sistem Saraf Pusat (SSP)}

Meskipun perbaikan dalam pengobatan kanker terus menerus dilakukan, toksisitas SSP tetap menjadi isu penting. Artikel review oleh Soussain et al. merangkum beberapa jenis komplikasi sistem saraf pusat akibat radioterapi, di antaranya ensefalopati akut yang memengaruhi hingga 50\% pasien setelah pemberian dosis tinggi atau fraksi radiasi, dan sindrom mengantuk yang terutama terlihat pada pasien anak, tetapi juga dapat memengaruhi pasien dewasa dalam 2 bulan pertama setelah radioterapi. Gejala yang menonjol adalah kantuk dan tidur berlebihan, mual, dan anoreksia; focal cerebral and spinal cord radionecrosis yang merupakan komplikasi akibat radiasi yang parah dan didefinisikan secara neuropatologis sebagai nekrosis dengan lesi vaskular berat (stenosis, trombosis, perdarahan, nekrosis vaskular fibrinoid). Komplikasi ini jarang terjadi selama 20 tahun terakhir dikarenakan adanya peningkatan keamanan protokol radiasi. ${ }^{28}$

\section{Xerostomia dan hiposalivasi}

Xerostomia didefinisikan sebagai kekeringan pada mulut karena disfungsi sekresi kelenjar ludah yang dapat disebabkan oleh beberapa kondisi, misalnya autoimun disorder, yang menyebabkan ketidaknyamanan mulut, nyeri dan kesulitan dalam berbicara. Penelitian Surjadi et al. pada pasien kanker kepala dan leher yang menjalani radioterapi, hasilnya yaitu $87,6 \%$ subjek menunjukkan penurunan 
laju salivasi. Dalam sebuah artikel review dikatakan bahwa penurunan (compromise) dalam fungsi salivasi dapat dilihat dalam waktu 1 hingga 2 minggu setelah radioterapi dan dapat bertahan setelahnya. Kecuali kerusakannya parah, fungsi saliva biasanya sembuh dalam waktu 2 tahun dari setelah radioterapi. Disfungsi kelenjar minimal bisa diamati pada dosis rata-rata 10 sampai 15 Gy dan dosis rata-rata $>40$ Gy pada kelenjar parotid menghasilkan suatu penurunan fungsi sebesar 75\%. Xerostomia dapat memiliki efek negatif pada kualitas hidup pasien yang sangat mengganggu kemampuan berbicara, mengunyah, menelan, dan merasakan. ${ }^{29}$

\section{Efek samping pada jantung \\ Kelainan jantung akibat radiasi biasanya disebut dengan istilah radiation induced heart desease (RIHD) yang menunjukkan keadaan klinis dan kondisi patologis cedera pada jantung dan pembuluh besar yang dihasilkan dari terapi radiasi kanker. Kelainan pada jantung dapat terjadi karena radiasi, antara lain kelainan pada perikardium, kelainan pada miokardium, kelainan pada arteri koroner, kelainan pada aterosklerosis, dan kelainan pada katup jantung. ${ }^{30}$}

Perkembangan terapi radiasi di Indonesia Perkembangan terapi radiasi di Indonesia bermula dari masuknya teknologi radiasi pada tahun 1927 berupa unit terapi sinar-X konvensional yang terutama digunakan untuk mengobati lesi kulit superfisial. ${ }^{31}$ Kemudian beberapa tahun pascakemerdekaan dilakukan penambahan kembali unit terapi superficial and deep X-ray di Rumah Sakit Umum Cipto Mangunkusumo (RSCM). Perkembangan radioterapi semakin terlihat dengan adanya pemasangan unit teleterapi Cobalt-60 pada tahun 1958 dan unit teleterapi Cesium-137 pada tahun 1964, kemudian beberapa pusat radioterapi mulai didirikan di beberapa daerah lainnya di pulau Jawa, seperti di Surabaya,
Semarang, Yogyakarta dan Bandung, yang sebagian besar dilengkapi dengan kilovoltage dan unit terapi cesium. Pada tahun 19801990 pemerintah mendirikan pusat radiasi tambahan di beberapa daerah khususnya di luar pulau Jawa yang dilengkapi dengan unit Telecobalt guna memudahkan akses bagi masyarakat untuk mendapatkan terapi radiasi untuk kanker. ${ }^{31,32}$

Berbagai metode terapi radiasi untuk terapi kanker telah digunakan di Indonesia. Pada tahun 1958, teknologi intracavitary radium branchytherapy mulai digunakan di departemen ginekologi RSCM. Teknologi Three-dimensional Treatment Planning System (3DTPS) juga telah tersedia di 11 pusat radioterapi. ${ }^{32}$ Pada bulan Februari tahun 2009, Menteri Kesehatan meresmikan pelayanan radioterapi terbaru di RSCM yang terdiri dari Stereotactic Radiotherapy (SRT) dan Stereotactic Radiosurgery (SRS), sebagai upaya terapi radiasi dengan presisi lokalisasi yang sangat tinggi dengan alat imobilisasi khusus untuk menghancurkan sel tumor tanpa merusak jaringan sehat sekitarnya; Intensity Modulated Radioteraphy (IMRT), sebagai teknologi paling mutakhir dalam terapi radiasi yang mampu menghadapi heterogenitas dari target radiasi. Onkologis dapat mengatur dosis radiasi yang irregular sesuai dengan kondisi tumor sekaligus menghindari paparan pada organ penting; dan 4D Adaptive IGRT, untuk memantau gerakan organ pada organ target saat dilakukan terapi penyinaran. Data terakhir pada Juni 2013 di Indonesia, terdapat 29 pusat pelayanan radioterapi (23 RS pemerintah dan 6 RS swasta) dengan total 41 alat radiasi. ${ }^{32,33}$

Beberapa jenis tindakan radiasi untuk terapi kanker yang telah dilakukan di Indonesia Berdasarkan penelusuran laporan pustaka, sampai saat ini beberapa jenis tindakan radiasi untuk terapi kanker yang telah dilakukan di Indonesia antara lain: radiasi eksterna telah dilakukan pada pasien dengan karsinoma 
serviks stadium IVB dengan metastasis paru. Pasien mendapatkan 25 kali radiasi dengan teknik konvensional lapangan whole pelvic AP-PA dan hasilnya tumor mulai mengecil sejak radiasi fraksi ke-5. ${ }^{34}$

Pada laporan kasus oleh Setyawan dan Gondhowiardjo di tahun 2015, digambarkan keberhasilan tindakan radiasi ex juvantibus pada dua buah kasus tumor regio pineal dan radioterapi pada kanker esofagus. Pada laporan kasus ini, pasien menjalani radiasi 3D-CRT lokoregional 50 Gy, 2 Gy per fraksi. ${ }^{35,36}$

Tindakan brakiterapi implan juga dilaporkan pada kasus oral tongue carcinoma sebagai booster paska radiasi eksterna dengan teknik plastic tube tanpa loop dan brakiterapi intraoperatif pada soft tissue sarcoma. Pasien menjalani radiasi 3D-CRT lokoregional 50 Gy, 2 Gy per fraksi. Kemoradiasi konkuren dengan cisplatin hanya bisa dilakukan satu kali karena keadaan umum pasien memburuk. 2 minggu setelah radiasi, pasien mulai bisa menelan makanan cair dan lunak dengan disfagia Grade $1 .{ }^{37}$

Selain penyakit keganasan, radioterapi juga dapat digunakan untuk terapi penyakit non-keganasan, seperti yang dilaporkan oleh Primasari dan Sekarutami pada tahun 2013 mengenai tindakan radiasi eksterna pada kasus Juvenile Nasopharyngeal Angiofibroma (JNA). Pada tatalaksana JNA, terapi utama adalah terapi pembedahan, terutama pada stadium awal ketika reseksi total masih dapat dilakukan. Pada tumor dengan lokasi sulit dijangkau oleh tindakan pembedahan, ekstensi intrakranial ataupun residu, radiasi eksterna memegang peranan penting dimana tingkat kurabilitasnya cukup tinggi yaitu 85$100 \%$ dengan efek samping lanjut yang masih dapat ditoleransi serta rekurensi minimal. ${ }^{38,39}$

Regulasi penggunaan teknologi radiasi di Indonesia

Berdasarkan ulasan yang telah dipaparkan sebelumnya, penggunaan teknologi radiasi dalam bidang kesehatan memberikan dampak yang positif dalam meningkatkan kualitus hidup masyarakat. Namun, tentu saja terdapat risiko yang besar dari penggunaan teknologi radiasi ini. Agar dapat menggunakannya dengan bijak, negara telah membuat peraturan yang ketat terkait penggunaan teknologi radiasi ini, yaitu UU Nomor 10 Tahun 1997 tentang ketenaganukliran. ${ }^{40}$ Negara juga membentuk lembaga-lembaga yang bertanggung jawab ${ }^{41}$ yang terdiri dari Badan Tenaga Atom Nasional (BATAN) yang bertugas dalam pemanfaatan tenaga nuklir dan Badan Pengawas Tenaga Nuklir (BAPETEN) yang bertugas untuk melaksanakan pengawasan segala kegiatan pemanfaatan tenaga nuklir.

Perizinan pemanfaatan bahan radioaktif diatur pada PP Nomor 29 Tahun 2008 tentang perizinan pemanfaatan sumber radiasi pengion dan bahan nuklir. Pemanfaatan ini sendiri dibagi menjadi tiga kelompok berdasarkan risiko keselamatan radiasi dan keamaanan sumber radioaktif. Dalam hal ini, pemanfaatan sumber radiasi dalam bidang kedokteran nuklir in vivo dan kedokteran nuklir terapi masuk ke dalam kelompok A sehingga alur perizinannya akan lebih ketat, sedangkan untuk kedokteran nuklir in vitro masuk dalam kategori B. ${ }^{42}$

Rumah sakit, sebagai salah satu penyedia layanan radiologi, memiliki peraturan tersendiri dalam proses pelayanan radioterapi yang dilakukan, hal tersebut diatur dalam Permenkes Nomor 1427 Tahun 2006 tentang standar pelayanan radioterapi di rumah sakit. Dalam Permenkes Nomor 1248 Tahun 2009 tentang penyelenggaraan pelayanan siklotron di rumah sakit, untuk rumah sakit kelas $A$ atau B, terutama yang ditetapkan sebagai RS pendidikan dapat menggunakan radionuklida dan/atau radiofarmaka yang dihasilkan oleh peralatan siklotron untuk pelayanan, pendidikan dan penelitian di bidang kesehatan. Siklotron sendiri merupakan suatu mesin (akselerator) yang mempercepat partikel 
secara melingkar, sehingga diperoleh energi kinetik yang tinggi dan berfungsi untuk menghasilkan radioisotop dengan waktu paruh yang rendah, seperti $13 \mathrm{C}$ dan $18 \mathrm{~F}$. Sumber daya manusia yang berkaitan dengan radioterapi (radiografer) juga diatur dalam Permenkes Nomor 81 Tahun 2013 tentang penyelenggaraan pekerjaan radiografer. ${ }^{43,44}$ Diharapkan dengan adanya peraturan yang ketat, masyarakat terlindungi dari bahaya penggunaan teknologi radiasi ini.

\section{Simpulan}

Teknologi radiasi telah ada di Indonesia sejak tahun 1927, dan hingga tahun 2013 terdapat 29 pusat pelayanan radioterapi di Indonesia. Radioterapi telah menjadi salah satu terapi yang penting dalam terapi kanker di Indonesia. Pemerintah Indonesia telah mendukung kemajuan teknologi ini dengan menerbitkan Permenkes Nomor 1427 Tahun 2006 tentang standar pelayanan radioterapi di rumah sakit dan Permenkes Nomor 81 Tahun 2013 tentang penyelenggaraan pekerjaan radiografer. Dengan semakin banyak dan berkembangnya fasilitas-fasilitas radioterapi di masa yang akan datang, diharapkan dapat mengurangi prevalensi penyakit kanker di Indonesia.

\section{Pendanaan}

Penulisan artikel review ini tidak didanai oleh sumber hibah manapun.

\section{Konflik Kepentingan}

Penulis menyatakan tidak terdapat konflik kepentingan dalam penulisan artikel ini.

\section{Daftar Pustaka}

1. Kementerian Kesehatan Republik Indonesia. Pusat data dan informasi kesehatan: Stop kanker. Jakarta: Kementerian Kesehatan Republik Indonesia; 2015.

2. NIH. Treatment for cancer-National Cancer Institute. [diunduh 15 Agustus 2017]. Tersedia dari: https://www.cancer.gov/ about-cancer/treatment.

3. Round CE, Williams MV, Mee T, Kirkby NF, Cooper T, Hoskin P, et al. Radiotherapy demand and activity in England 2006-2020. Clin Oncol (R Coll Radiol). 2013;25(9):522-30. doi: 10.101 6/j.clon.2013.05.005

4. Liauw SL, Connell PP, Weichselbaum RR. New paradigms and future challenges in radiation oncology: An update of biological targets and technology. Sci Transl Med. 2013;5(173):173sr2. doi: 10. 1126/scitranslmed.3005148.

5. Baskar R, Lee KA, Yeo R, Yeoh KW. Cancer and radiation therapy: Current advances and future directions. Int $\mathrm{J}$ Med Sci. 2012;9(3):193-9. doi:10.7150/ijms.3 635.

6. Malicki J. Medical physics in radiotherapy: The importance of preserving clinical responsibilities and expanding the profession's role in research, education, and quality control. Rep Pract Oncol Radiother. 2015;20(3):161-9. doi:10.1016 /j.rpor.2015.01.001.

7. Mehta SR, Suhag V, Semwal M, Sharma N. Radiotherapy: Basic concepts and recent advances. Med J Armed Forces India. 2010;66(2):158-62. doi: 10.1016/ S0377-1237(10)80132-7.

8. Laramore GE. Role of particle radiotherapy in the management of head and neck cancer. Curr Opin Oncol. 2009; 21(3):224-31. doi:10.1097/CCO.0b013e $328329 b 716$.

9. Schardt D, Elsässer T, Schulz-Ertner D. Heavy-ion tumor therapy: Physical and radiobiological benefits. Rev Mod Phys. 2010;82(1):383-425. doi:10.1103/RevM odPhys.82.383. 
10. Orth M, Lauber K, Niyazi M, Friedl AA, Li M, Maihöfer C, et al. Current concepts in clinical radiation oncology. Radiat Environ Biophys. 2014;53(1):1-29. doi: 10.1007/s00411-013-0497-2.

11. Bovi JA, White J. Radiation therapy in the prevention of brain metastases. Curr Oncol Rep. 2012;14(1):55-62. doi: 101007/s11912-011-0208-6.

12. Rödel C, Trojan J, Bechstein WO, Woeste G. Neoadjuvant short-or long-term radio(chemo)therapy for rectal cancer: how and who should be treated?. Dig Dis. 2012;30(2):102-8. doi: 10.1159/0003420 38.

13. Guedea F. Perspectives of brachytherapy: patterns of care, new technologies, and "new biology". Cancer Radiother. 2014; 18(5-6):434-6. doi: 10.1016/j.canrad.20 14.07.143.

14. Zhuang H, Zhao X, Zhao L, Chang JY, Wang P. Progress of clinical research on targeted therapy combined with thoracic radiotherapy for non-small-cell lung cancer. Drug Des Devel Ther. 2014;8:667-75. doi: 10.2147/DDDT.S61 977.

15. Ho K, Lin H, Ann DK, Chu PG, Yen Y. An overview of the rare parotid gland cancer. Head \& Neck Oncol. 2011;3:40. doi:10.1186/1758-3284-3-40.

16. Bhandare N, Mendenhall WM. A literature review of late complications of radiation therapy for head and neck cancers: Incidence and dose response. Nucl Med Radiat Ther. 2012;S2:009. doi: 10.4172/2 155-961 9.S2-009.

17. Wong RS. Apoptosis in cancer: from pathogenesis to treatment. J Exp Clin Cancer Res. 2011;30(1):87. doi:10.1186/1 756-9966-30-87.

18. White E. The role for autophagy in cancer. J Clin Invest. 2015;125(1):42-6. doi:10.1172/JCI73941.

19. Mathew R, Karantza-Wadsworth V, White E. Role of autophagy in cancer. Nat Rev
Cancer. 2007;7(12):961-7. doi:10.1038/n rc2254.

20. Proskuryakov SY, Gabai VL. Mechanisms of tumor cell necrosis. Curr Pharm Des. 2010;16(1):56-68.

21. Caruso Ra, Branca G, Fedele F, Irato E, Finocchiaro G, Parisis A, et al. Mechanisms of coagulative necrosis in malignant epithelial tumors (review). Oncol Lett. 2014;8(4):1397-402. doi: 10.3892/ol.20 14.2345.16(1):56-68.

22. Campisi J. Aging, Cellular Senescence, and Cancer. Annual review of physiology. 2013;75:685-705. doi:10.1146/annurevphysiol-030212-183653.

23. Chan K-S, Koh C-G, Li H-Y. Mitosistargeted anti-cancer therapies: where they stand. Cell Death Dis. 2012;3(10):e411. doi:10.1038/cddis.2012.148.

24. Ganapati NPD, Djakaria H. Tinjauan pustaka: Efek samping radiasi pada jantung. J Indones Radiat Oncol Soc. 2016;7(1):26-35.

25. Baudino TA. Targeted cancer therapy: The next generation of cancer treatment. Curr Drug Discov Technol. 2015;12(1):3-20.

26. National Cancer Institute. Common terminology criteria for adverse events (CTCAE) common terminology criteria for adverse events v4.0 (CTCAE). [diunduh 23 Agustus 2017]. Tersedia pada: https:// evs.nci.nih.gov/ftp1/CTCAE/CTCAE_4. 03_2010-06-14_QuickReference_5x7pdf.

27. Hoppe BS, Laser B, Kowalski AV, Fontenla SC, Pena-Greenberg E, Yorke $\mathrm{ED}$, et al. Acute skin toxicity following stereotactic body radiation therapy for stage I non-small-cell lung cancer: who's at risk?. Int J Radiat Oncol Biol Phys. 2008;72(5):1283-6. doi: 10.1016/j.ijrobp .2008.08.036.

28. Soussain C, Ricard D, Fike JR, Mazeron JJ, Psimaras D, Delattre JY. CNS complications of radiotherapy and chemotherapy. Lancet. 2009;374(9701):163 9-51. doi: 10.1016/ 
S0140-6736(09)61299-X.

29. Surjadi N, Amtha R. Radiotherapy reduced salivary flow rate and might induced C. albicans infection. J Dentistry Indones. 2012;19(1):14-9. doi: 10.14693/j di.v19i1.124

30. Madan R, benson R, Sharma DN, Julka PK, Rath GK. Radiation induced heart disease: Pathogenesis, management and review literature. J Egypt Natl Canc Inst. 2015;27(4):187-93. doi: 10.1016/j.jnci.2 015.07 .005

31. Djakaria M. Radiotherapy. In: Rukmono, Wiknjosastro H, Samino. History of Cipto Mangunkusumo Hospital and Faculty of Medicine University of Indonesia. Jakarta: Balai Penerbit FKUI; 1989.

32. Gondhowiardjo S, Prajogi G, Sekarutami S. History and growth of radiation oncology in Indonesia. Biomed Imaging Interv J. 2008;4(3):e42. doi:10.2349/biij.4.3.e42.

33. Perhimpunan Onkologi Radiasi Indonesia. Usulan rencana straegik roadmap pengembangan radioterapi Indonesia [diunduh 22 Agustus 2017]. Tersedia dari: http://www.pori.or.id/pori-activity/ usulan-rencana-strategik-dan-roadmappengembangan-radioterapi-indonesia.

34. Hartanto S, Djakaria HM. Peran radioterapi pada karsinoma neuroendokrin jenis karsinoma sel kecil pada serviks. J Indones Radiat Oncol Soc. 2016;7(1):1825.

35. Setyawan A, Gondhowiardjo S. Terapi radiasi ex juvantibus pada tumor regio pineal. J Indones Oncol Soc. 2016;7(1): $10-7$.

36. Novirianthy R, Djakaria M. Brakiterapi implan pada oral tongue carcinoma. J Indones Radiat Oncol Soc. 2012;3(1):14-
21.

37. Indarti AF, Sekarutami SM. Radiasi pada Kanker Esofagus. J Indones Radiat Oncol Soc. 2013;4(2):70-6.

38. Primasari M, Sekarutami SM. Peranan radiasi eksterna dalam tatalaksana juvenile nasopharingeal angiofibroma. J Indones Radiat Oncol Soc. 2013;4(2):6170.

39. Marlina YS, Sekarutami SM. Brakiterapi intraoperatif pada soft tissue sarkoma. J Indones Radiat Oncol Soc. 2012;3(1):2230 .

40. Humas Sekretariat Kabinet Republik Indonesia. Penggunaan tenaga nuklir di Indonesia: Aspek hukum | Sekretariat Kabinet Republik Indonesia [diunduh 23 Agustus 2017]. Tersedia dari: http:// setkab.go.id/penggunaan-tenaga-nuklirdi-indonesia-aspek-hukum.

41. Republik Indonesia. Peraturan Pemerintah Republik Indonesia Nomor 29 Tahun 2008 tentang Perizinan Pemanfaatan Sumber Radiasi Pengion dan Bahan Nuklir; 2008.

42. Kementerian Kesehatan Republik Indonesia. Peraturan Menteri Kesehatan Republik Indonesia Nomor 780 Tahun 2008 tentang Penyelenggaraan Pelayanan Radiologi; 2008.

43. Kementerian Kesehatan Republik Indonesia. Keputusan Menteri Kesehatan Republik Indonesia Nomor 1427 tentang Standar Pelayanan Radiografi di Rumah Sakit; 2006.

44. Kementerian Kesehatan Republik Indonesia. Peraturan Menteri Kesehatan Republik Indonesia Nomor 1248 Tahun 2009 tentang Penyelenggaraan Pelayanan Siklotron di Rumah Sakit; 2009. 